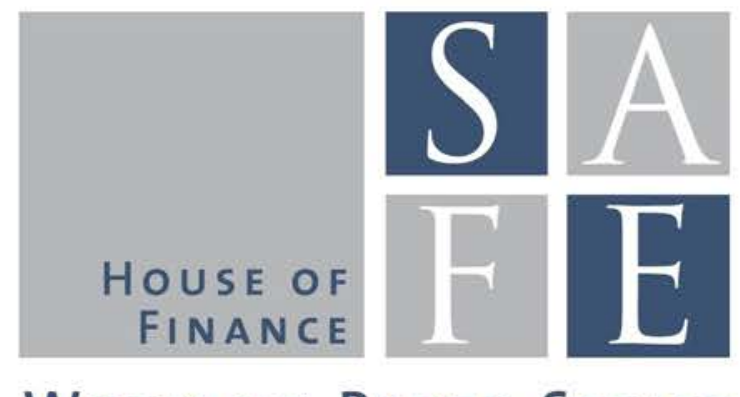

WORKING PAPER SERIES

Vanessa Endrejat - Matthias Thiemann

\title{
Reviving the Shadow Banking Chain in Europe: Regulatory Agency, Technical Complexity and the Dynamics of Co- Habitation
}

SAFE Working Paper No. 222

SAFE I Sustainable Architecture for Finance in Europe A cooperation of the Center for Financial Studies and Goethe University Frankfurt 


\title{
Reviving the Shadow Banking Chain in Europe: Regulatory Agency, Technical Complexity and the Dynamics of Co- Habitation
}

\author{
Vanessa Endrejat, Goethe University Frankfurt \\ Matthias Thiemann, Sciences Po Paris \& SAFE
}

June 2018

In recent years European financial regulation has experienced a tremendous reorientation with respect to the shadow banking system, which manifested first and foremost in its reframing as market-based finance. Initially identified as a source of systemic risk certain initiatives did not only fall much behind the envisaged changes but all to the contrary have been substantially modified in a way that they now aim at revitalizing these activities. The reorientation of European regulatory agency on shadow banking post-crisis, from curtailing it to facilitating resilient market-based finance, has been a cause for irritation by academic observers, dismissed by some as mere rebranding or taken as a sign of regulatory capture. All to the contrary, this paper documents the central role of regulatory agency in shadow banking's reconfiguration. It does so by analyzing the European initiatives concerning the regulation of Asset-Backed Commercial Paper (ABCP) and another prime example of shadow banking, Money Market Mutual Funds (MMFs). Based on documentary analysis and expert interviews we trace the way the recently published EU frameworks for MMFs and ABCP have been designed (in particular the STS, CRR and MMF regulation in 2017). Furthermore, we show how they have been transformed in such a way that their final versions allow to re-establish the shadow banking chain linking MMFs, the ABCP market and arguably the regular banking system. This transformation is driven by a new form of pro-active European regulatory agency which aims at creating a regulatory infrastructure able to sustain the orderly flow of real economy debt. Far from being captured by the industry, they did so consciously and in cooperation with private actors in order to maintain a channel for credit creation outside of bank credit, a task made more complicated by the rushed politicized final negotiations coupled with technical complexity. This paper thereby contributes to a new strand of literature, seeing the creation and reconfiguration of the shadow banking system as characterized by the active and conscious role of state actors.

\footnotetext{
${ }^{1}$ The authors gratefully acknowledge the support of SAFE at the House of Finance in Frankfurt. Earlier drafts have been presented at the Finance and Society Conference 2017 in London, the ECPR Joint Sessions 2018 in Nicosia and the ECPR Standing Group Conference 2018 in Paris. The authors thank the participants of these events for their helpful comments.
} 


\section{Introduction}

What drives European financial regulatory initiatives ten years after the financial crisis and what constrains and shapes their intervention in financial markets? To approach these questions, we will look at regulatory reforms affecting a crucial part of the initially demonized shadow banking system, Asset-Backed Commercial Paper (ABCP) and Money Market Mutual Funds (MMFs) and their link to banks. In July 2007 this intricate relationship, defined here as the 'shadow banking chain', became infamous through the failure of IKB Deutsche Industriebank (IKB), which brought to the fore how banks' engagement in arbitrage activities in capital markets constructed a highly interconnected and fragile system. When markets came under distress, IKB's large portfolio of securitized products which the bank had placed off-balance sheet into ABCP conduits returned on the balance sheet, de facto bankrupting IKB. This return on the balance sheet was caused by the refusal of the major investors into the ABCP conduits, MMFs - themselves highly prone to runs -, to refinance them. Consequently, banks had to step in to avert the worst in both cases, ABCP conduits and MMFs. These incidents demonstrated the inherent risks to the financial system that these institutions pose, which might not be big in size but systemic through their interconnectedness (Lysandrou and Nesvetailova 2014). But while US regulators chose a strict approach on exactly these institutions, more recently European regulators started an initiative to destigmatize $A B C P$ securitization while simultaneously publishing an MMF reform that instead of subjugating them to bank-like regulation is more than likely to sustain these market segments. This paper seeks to analyse how European regulators, embedded in their policy network and subject to broader contextual factors, began to reconsider these market segments and used their bounded discretion to reconstruct those parts of these financial instruments, which they understood as channels for real economy debt.

Based upon process tracing, 13 expert interviews and a document analysis we will analyze the drafting of the European MMF and ABCP regulation and show how the changing structural context, mediated through the policy network, led European regulators to embrace shadow banking institutions to ensure the orderly flow of credit to the real economy. Regulators aimed at creating a 'regulatory fix' for real economy debt (Fernandez and Wigger 2016) and they did so in a co-productive manner with private actors to handle the intricacies of the two highly technical subjects (Dorn 2016). Rather than being captured regulators acknowledged the high sensitivity of the low-margin business towards regulatory costs and the overall regulatory infrastructure as decisive factor for their aim to craft the infrastructure for real economy debts' orderly flow through the financial system. The current literature on shadow banking regulation post-crisis entirely misses European regulators' intentional intervention in financial markets with the aim to provide for regulatory infrastructure supporting real economy debt flow while protecting against market downturns. 
Scholarly work either analyses the evolution of shadow banking by focusing on the agency of central banks, interacting with banks and non-bank actors (Braun 2016, Gabor 2016) or banks' activities of regulatory arbitrage (Pozsar 2008; Pozsar et al 2010, Bell and Hindmoor 2015a). However, it neglects the agency of regulators in consciously embracing financial activities outside of, but deeply intertwined with the regular banking system. By taking the agency of regulators seriously, our analysis of the redesign of central shadow banking institutions (MMFs and $A B C P$ ) shows how changes in the broader structural contexts affected regulators' strategies and their policy networks. They are confronted with the genuine difficulty to serve the public interest and to formulate a unified approach to tackle the particularities of financial regulations: the financial systems' intertwined nature with the real economy and its highly dynamic and complex nature. They do so by acting within the bounded discretion of their institutional environment in which they introduced a new style of regulation defined by Dorn (2016) as cohabitation. The analysis of the MMF and ABCP's drafting period points to the large degree of conscious regulatory agency at the EU level in order to revive this shadow banking chain. Embedding the regulatory process in its broader political and economic context (Engelen 2015, Streeck 2009), our analysis will stress the importance of taking into account how regulators are constrained and enabled by their institutional environment which in turn mediates and absorbs these contextual factors.

The paper first gives an introduction to the scholarly work assessing the rise of the shadow banking system so far, outlining how their focus lies either on the agency of the regulated or more recently, on the agency of central banks as important explanatory factors. Against this backdrop, we will conceptualize the decisive aspects shaping regulators in their agency, which is on one hand subject to the dynamics of the policy networks they are embedded in while on the other hand influenced by structural factors which are most prominently expressed in changing discourses. The subsequent section then gives a short primer on the shadow banking chain, based upon which the fifth section will delineate the changes undertaken to the MMF and $A B C P$ reform throughout their drafting and determine the structural and institutional aspects that paved the way for aligning the two regulations. Finally, we discuss our findings and outline the implications of the findings for our understanding of the shadow banking system.

\section{Literature Review}

In broad strokes, two opposing views on shadow banking, or how it is recently framed market-based banking, can be discerned. The first one sees shadow banking as an outgrowth of rule bending activities of banks, evading capital requirements (Thiemann 2018) and asks when and under which conditions regulators are catching up (Funk and Hirschman 2014). The focus is primarily placed on the agency and motivation of the regulated to understand market developments and on regulators to understand the 
(belated) intervention (Thiemann and Lepoutre 2017). Linking the development of shadow banking activities to fractured policy fields (Funk and Hirschman 2014, Thiemann 2018), the literature is pointing to agency of the regulated as the primary explanation (Bell and Hindmoore 2015, Hardie et al 2013). Research on the shift to shadow banking activities in banking systems has acknowledged the structuring role of banking and other regulations (Hardie et al 2013), but it has not properly focused on the factors driving regulatory agency. Rather, it has emphasized the agency of bankers within these regulatory constraints (Acharya and Schnabl 2010; Hardie and Howarth 2013, p. 51; Hardie et al. 2013, p. 697).

A second strand of literature has pointed to the central role of state agency in the development of the shadow banking actors and activities. Going beyond regulatory arbitrage and the ensuing regulatory dialectic (Kane 1988, 2008), O'Sullivan (2007) has analyzed the move towards market-based banking in France as a conscious choice of regulators and lawmakers, with banks acting out institutional change prepared for by regulators and lawmakers. The latter had studied and sought to adapt their financial system to institutional changes occurring in the US (O' Sullivan 2007). More recent contributions by Gabor (2016) and Gabor and Ban (2016) have documented the active intervention and central role of the European Central Bank and Braun (2018) extends this argument of "governing through financial markets" to post-crisis developments regarding the revival of securitization (s. also Braun and Huebner 2018, Braun et al 2018). Closer to our argument, Fernandez und Wigger (2016) point to the role of state actors in the creation and evolution of credit channels outside of banks' balance sheets and subsequently stress the "need to create a deeper understanding of the statecraft that produces the rescaled financial architecture that allows for debt creation in the financial core" (p. 425).

Another approach that focuses on regulators' interests beyond their own involvement in the market is provided by Dorn (2016) describing a new logic of "closer cooperation between regulators and markets" which culminates in a post-crisis project where public and private actors come together in strategic terms and form a cohabitation (p. 85). This constitutes a 'recalibration' of both the content (appropriate design) and the mode (public-private co-production) of regulation. Furthermore, he argues that the qualitative changes happened in the "techniques or policy instruments" but not in “overarching goals" (Dorn 2016: 101). Thus, following Mügges (2013) proposed "shift in perspective from finance as a business sector to finance as credit creation and allocation" (p. 459) allows to see these goals of regulators clearer, whereby the central rational for European regulators is to build an appropriate regulatory infrastructure for a continuous flow of debt into the real economy. As argued by Fernandez and Wigger (2016), prospering shadow banking institutions are defined by "states creating the necessary regulatory infrastructure that enlarges the capacity of the wider economy to take on more debt" (p. 409). But what determines the creation of the appropriate regulatory 
infrastructure and the capacity of states to create this regulatory infrastructure? To approach this question the next section will outline our theoretical apparatus to analyze the agency of regulators embedded in their policy and rule-making networks ${ }^{2}$ and confronted with broader structural changes such as the changing face of finance.

\section{Theory - Positive regulatory agency and the shadow banking system}

To analyze these dynamics of cohabitation and regulatory agency within it, that is to say when and why regulators act/intervene in markets in certain ways and what conditions this regulatory agency, it is important to understand regulators (in the sense of rule makers) not in isolation, but to consider them in their regulatory environment and the wider societal field (Hutter 1997). To do so, we combine insights of an expanded historical institutionalism ${ }^{3}$ perspective (Bell 2011, Archer 2003) with the literature on policy networks (Mayntz 2003, Rhodes 1997). On one hand, we recognize that actors "cannot simply be assumed to have a fixed (and immutable) preference set" and consequently frame regulators as "strategic, seeking to realize complex, contingent and often changing goals" (Hay and Wincott 1998: 954). On the other hand, regulators are enabled and constrained by their institutional environment which itself is situated in a broader structural setting based on material or ideational phenomena (Bell 2011, Bell and Hindmoor 2015a: 3). Such an account situates strategic agents (microlevel) in the institutional meso-level environment according to which they enjoy a bounded discretion and that mediates their relation to the wider political and social setting they are embedded in by absorbing and shaping policy discourses from the macro-level.

To capture the institutional meso-level we use the concept of policy networks, which includes public rule-makers as well as rule-takers (Marin and Mayntz 1991) and is particularly appropriate for the analysis of EU governance, which „takes place in polycentric, multilevel policy networks of public and private actors" (Peterson 2003: 18). The governance literature using the term policy network is focusing on the veto players and coordination requirements between public and private but also between different public agents to understand the evolution of public policy. To better grasp the latter, we introduce a further distinction between the networks that are comprised of public and private agents and those in which only public agents interact with each other. Thus, we use the term rulemaking network to denote the different rule-making agents involved at the EU level and separate coordination efforts in times when public agents are 'thrown back on themselves', negotiating without

\footnotetext{
2 The rule-making network entails the European bodies that pass the legislative text: The European Commission, the Council and the Parliament. The policy network is comprised of all public and private agents involved in the regulatory process.

${ }^{3}$ As Deeg and Posner (2016) outlined "there is considerable untapped potential for historical institutionalism as an analytical approach for studying European financial market integration and regulation" (p. 438-9).
} 
being capable of consulting private agents beforehand. Contrary to that, the term policy network goes beyond that and includes the interested private agents participating in the rule-making process.

This perspective allows us to place regulatory action in the sense of rule-making in its macro(structural) and meso-(institutional) context. In terms of the latter, European financial regulation has experienced a considerable upgrade since the crisis which created new EU level tasks. This led to a significant shift of competences to the EU level (Falkner 2016: 227; Kudrna 2016), which transformed it into a 'transmission belt' between the national and international level after the crisis (Quaglia 2015). However, as our case study shows, European regulatory action soon moved beyond just being a transmission belt to using its new competencies for the active creation of a regulatory infrastructure amenable to credit flows into the real economy. Besides this, the policy network is widely stable with the same actors dominating decision-making, a certain degree of permeability institutionalized for instance through stakeholder consultations and in particular the same degree of dependency upon other actors for expertise. ${ }^{4}$ Nevertheless, more recently we see a change in the informal institutional environment, expressed in the regulators attitude towards the mode of financial regulation and attempting to build a partnership with market actors (Dorn 2016).

Regarding the structural context, in analyzing regulatory action with respect to the financial sector, we take critical political economists' appeal not to treat finance just like any other sector, but to take its substantive importance for current capitalism seriously (Mügge 2013). Capitalism in the EU, just as elsewhere is increasingly subject to a finance-led growth regime (Boyer 2000), in which the expansion of finance is a substantial ingredient for growth. The second dimension of macro-structure are the dominant discourses at the EU level, which structure the understanding of the challenges and goals to be pursued at the micro-level. These micro-level strategies are shaped by the meso-level institutional context in which agents are situated (Moschella and Tsingou 2013, 201), in turn defining the way different actors position and relate to each other. This perspective points not only to the competencies and the timing of the rule-making process as institutional constraints, but also the sources of expertise which are drawn upon by different rule-making actors at the EU level as they prepare legislative proposals (Mudge and Vauchez 2012) and the modalities of input and influence by the private sector (Tsingou 2015). Nevertheless, in doing so they are restricted by the timing and sequence of the reform process, which decisively defines the "political trajectories by conditioning the interests of and options available to actors" (Moschella and Tsingou 2013: 20). Consequently, to analyze regulatory agency, we have to understand the micro-, meso- and macro-level they are embedded in and how they dialectically define regulators market interventions.

\footnotetext{
${ }^{4}$ Peterson (2003) outlines three key variables as defining the type of policy networks, its relative stability, the network's relative insularity and strength of resource dependencies (p. 4).
} 
This framework is particularly appropriate with respect to shadow banking, where positive regulatory agency requires coordination of several actors on complex and sensitive regulatory matters. With respect to the issue of coordination, literature points to the insularity of the policy network from outside influences, its stability in terms of membership as well as the use of common language and skill set as factors facilitating coordination (Peterson 2003, Seabrooke and Tsingou 2009). On the other hand, issue complexity as well as politicization are factors identified as hampering coordination. Reconstructing the shadow banking chain implies the need for coordination on different projects to permit the interlocking of different financial instruments into one chain of financing. As we will see, regulatory agency at the EU level was conditioned by the structural setting and the larger discourses reflecting the Zeitgeist, reorienting regulatory strategies to reconstruct the shadow banking chain. Complexity and the need for intense coordination in a rushed process of negotiation at the end of the legislative process, however, were obstacles which were difficult to overcome. But before turning to the analysis of the process itself, we will first shortly outline some of the key features of the complexity residing in this interlinkage between MMFs, ABCPs and banks. While MMFs as well as ABCP conduits engage extensively in maturity transformation and hence appear bank like, they are also very sensitive to regulatory costs, thus depending on appropriate rule sets to prosper.

\section{Shadow Banking Chain - A Primer}

In this paper, we take a disaggregated view on the shadow banking system, which helps us to differentiate between shadow banking's peripheral and central parts (Lysandrou and Nesvetailova 2014) and analyze their fragile interlinkages (Pozsar et al 2010). While short-term investors use ABCPs as 'value container' (Lysandrou and Nesvetailova 2014: 263), MMFs are part of the cash management processes of banks and large wholesale investors, as they have a cash-like status but provide a small uptick (EP 2015: 14). In their search for yield, coupled with the need for liquid short-term investments, MMF managers then invest in ABCPs (redeemability usually below 30 days), which in turn invest in longer term assets, often overcollateralized or securitized loans. Banks stand by these (multi-seller) $A B C P$ conduits, in that they channel their clients' debt into these vehicles, permitting access to capital markets to clients which otherwise are too small. 
Figure 1: The shadow banking chain with a multi-seller conduit

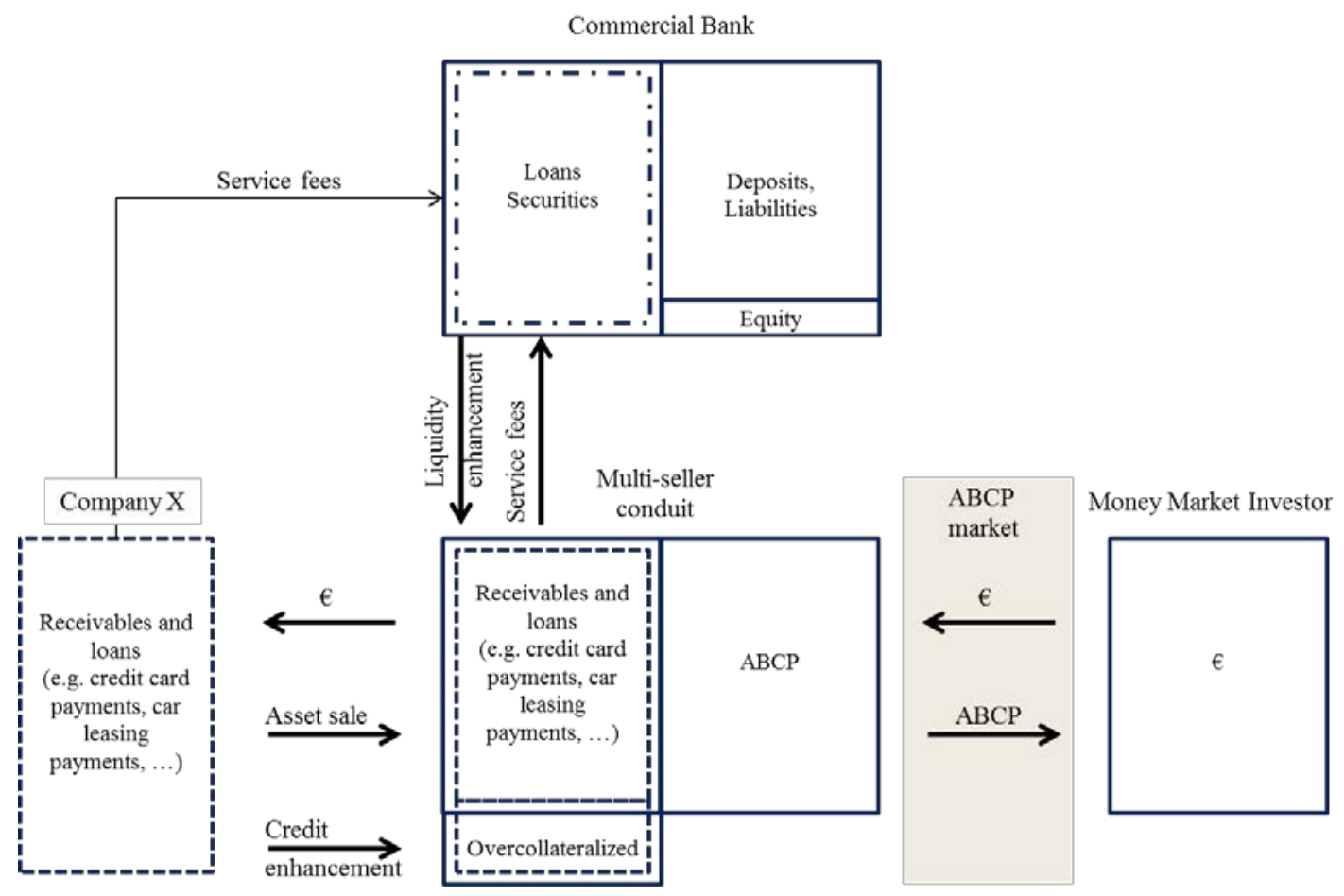

(courtesy Thiemann and Lepoutre 2017)

The interconnection between banks, MMFs and the ABCP market depicted in figure 1 becomes of central concern not so much because of their individual size but due the link it creates between the regular banking sector and the two central shadow banking institutions. They are characterized by their bank-like (short-term) maturity transformation, and their sensitivity towards regulatory costs brought about by the low-margin business they engage in (Hellwig 2010). Consequently, their profitability is largely based on the overall length of maturity transformation it achieves, from daily MMF accounts at the beginning of the chain towards the refinancing of loans and securitized products of up until 30 years which were placed into $A B C P$ conduits before the crisis. Amplified by their interdependence, these effects create a fragile chain of maturity transformation. This chain then is very likely to vanish, if affected by tougher (bank) regulatory costs, threatening to consume all the profits generated or by regulation limiting the extent of maturity transformation. ${ }^{5}$ The crucial implication resulting from this business model is a trade-off between benefits (providing a channel of debt) and risks (e.g. run on MMFs).

Before the crisis, this intricate relationship did not only emerge because of the competitive pressure within the financial sector, but it took the appropriate regulatory structure to allow banks to discover 'capital markets as a source of profit in their own right' (Mügge 2010: 8). Consequently, due to

\footnotetext{
${ }^{5}$ If MMFs are regulated like banks, they vanish because they are not designed in a way to satisfy such requirements (e.g. core capital requirements) and in terms of ABCPs, if regulatory costs (for banks) go up too much, there is no business in it.
} 
differences in regulatory treatment across Europe we find the $A B C P$ and $M M F$ market to be concentrated in few European countries, where accounting rules ${ }^{6}$ allowed banks to engage in $A B C P$ trading (Thiemann 2018) or beneficial tax treatment made MMFs an attractive money market instrument (Baklanova and Tanega 2018). In the immediate aftermath, regulatory efforts culminated on the European level and new regulation caused a considerable restructuring of the market (Interview 12). Regulatory concerns at that moment bear a strong macroprudential imprint and action is dominated by transnational and US intervention. In this context, the EU predominantly acted as 'transmission belt' between the national and international level (Quaglia 2015). All in all, the crisis related implosion of the chain and regulatory interventions in its aftermath mutually shaped market structures in the immediate post-crisis era. ${ }^{7}$

However, endowed with new competencies which led to a decisive shift of regulatory powers towards the European level (Falkner 2016), European regulators increasingly started to assume a new role from 2012 onwards: creating the appropriate regulatory infrastructure and shaping the European financial system, among other things focusing on the shadow banking chain and its single institutions. The following analysis will show how the relevant transformation started, once the post-crisis dust had settled and European regulators developed an agency in their own right.

\section{From curtailing shadow banking to making markets reach the real economy}

In the following, we will analyze the process of the new regulation for ABCPs and MMFs, which were set up under different circumstances and intentions but have been aligned throughout the regulatory process. Figure 2 captures the key events in the legislative process of both regulations and the timely manner in which they moved towards each other. It will be outlined how both regulations have been restructured in a way that is supposed to provide the appropriate European regulatory infrastructure for both industries to continue but also to sustain their relationship.

\footnotetext{
${ }^{6}$ The transposition of Basel I into national accounting rules was in some European countries designed in a way that allowed for $0 \%$ capital requirements compared to the general $8 \%$ capital requirements for banks. However, the capital requirements widely differed between Euro area states due to the distinct national accounting rules (Thiemann 2018).

7 The most consequential regulations have been the Committee of European Securities Regulators (CERS) guidelines for MMFs and the CRD updates affecting ABCP (Interview 6, 12).
} 
Figure 2: The alignment of the European MMF and $A B C P$ regulation

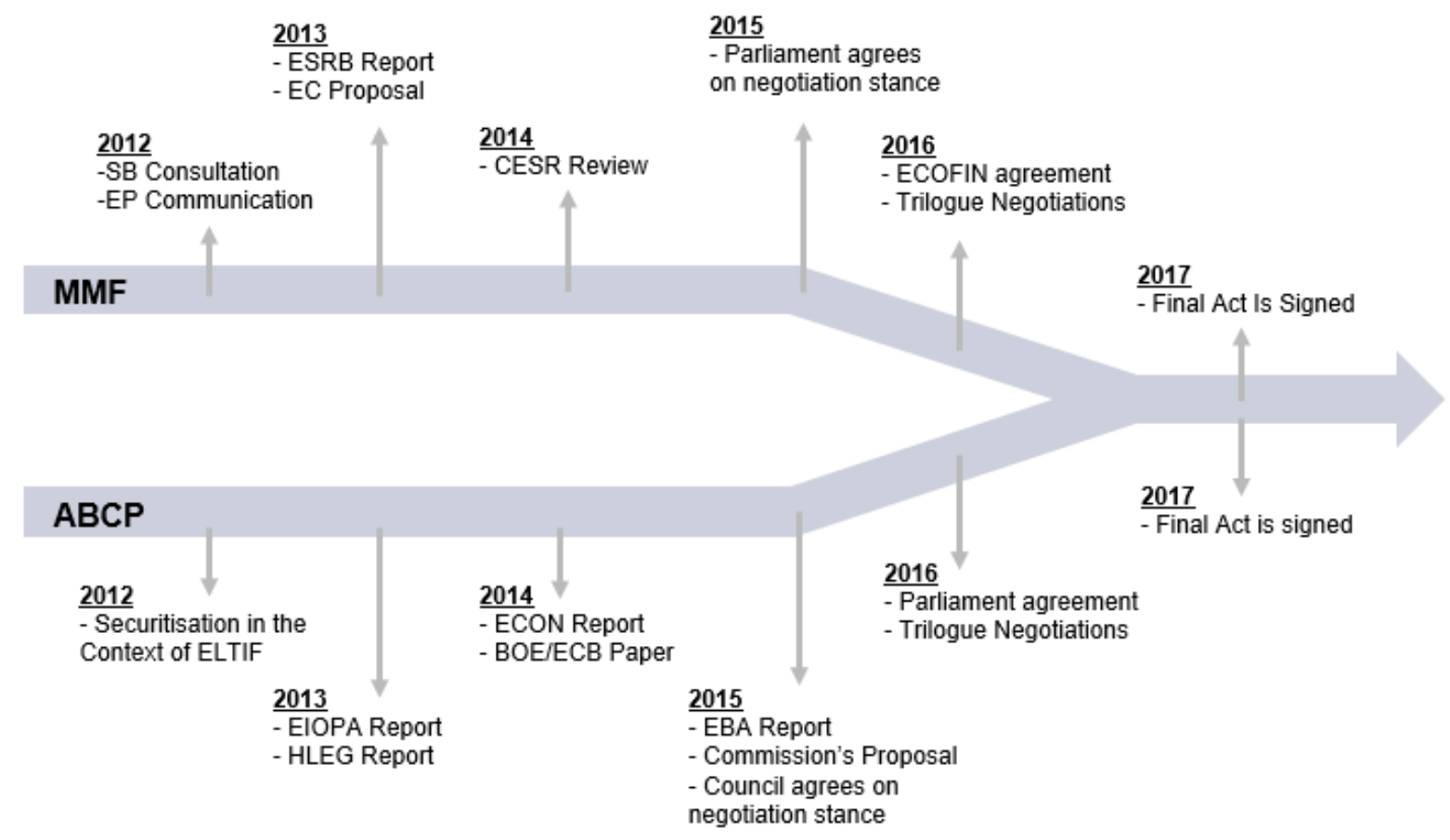

When the European Commission published its proposal for a regulation on Money Market Funds $(M M F R)^{8}$ in 2013, it triggered a huge outcry by the industry (e.g. IFSC 2013). In contrast, when the final $\mathrm{MMFR}^{9}$ was published the industry reacted in a surprisingly positive manner. For example, industry representatives stated that "the cautious reform is unlikely to disrupt the EU MMF market or to trigger substantial outflows from the sector as a whole" (ibid: 4). While this is remarkable in the first place, when looking at the significant changes undertaken to the proposal throughout the drafting process it is not surprising at all. But unlike several other reform efforts that are criticized for being watered down during the legislative process, the MMFR rather went through a noteworthy transition. This culminated in the abolishment of for instance the sunset clause and capital buffers, while a new category of MMFs was introduced that was not envisaged in the beginning and did not exist so far. Initial considerations aimed at regulating MMFs like banks, as suggested by the Financial Stability Board (FSB), proclaimed by the European Parliament in 2012 and then proposed by the European Commission in 2013.

Nevertheless, the final MMFR left the core of the industry untouched while accommodating changes that already took place. In contrast to that, the regulatory approach towards ABCPs did not aim at

\footnotetext{
${ }^{8}$ Proposal for a Regulation of the European Parliament and of the Council on Money Market Funds, 4.9.2013 $\operatorname{COM}(2013) 615$ final, https://eur-lex.europa.eu/legal-content/EN/TXT/PDF/?uri=CELEX:52013PC0615\&from=EN. ${ }^{9}$ Regulation (EU) 2017/1131 of the European Parliament and of the Council of 14 June 2017 on money market funds, OJ L 169, 30.6.2017, p. 8; https://eur-lex.europa.eu/legalcontent/EN/TXT/PDF/?uri=CELEX:32017R1131\&from=EN.
} 
restricting them but rather at reviving the market. Nevertheless, its early drafts would also have triggered a tremendous reshuffling within the market and was criticized as "hardly feasible" (TSI 2015). And even after some significant changes the industry still was more than concerned stating that "frustrations remain" (Freshfields 2016: 6). These concerns vanished when European regulators ended their Trilogue negotiations and loosened the most critical requirements in the final regulation. What is of particular relevance for the empirical puzzle presented here is that this happened in the same period of time as the restructuring of the MMFR.

In the analysis of the MMFR and the ABCP regulations ${ }^{10}$ we will show how the interplay between the regulatory micro-level, their meso-level defined by the policy and rule-making network and discursive macro-level factors, first paved the way for reconsidering the regulatory approaches, but soon hampered their coordination through its high technicality and politicized nature. This impeded the drafting of simple regulations and rather let the regulations culminate in a 'most of' instead of a 'best of' proposed requirements where the 'devil lies in the details' (Interview 7, 12). The following analysis of the three phases of both drafting processes will outline how this was brought about by European regulators becoming increasingly sensitive towards possible unintended outcomes of the reforms, which let them form a cohabitation with private actors.

\section{First Phase (2012-2014) Schizophrenia on shadow banking}

This first phase is characterized by a reconsideration of the regulatory reforms' potential impacts and the broadening awareness of regulators towards the dynamics of a prevailing finance-led growth regime in Europe demonstrating the changed attitude towards regulation overall. Nevertheless, at the end of the phase the European Commission proposes an MMF regulation with the power to restructure the market while the new rules on securitizations are not even publicly debated. The context of the regulatory work going on between 2012 and 2014 was still restricted by discourses about the regulatory failure to prevent the crisis, but with increasing importance of growth enhancing measures laying the ground for a new European regulatory agency that pursues its own strategies.

However, in 2012 itself, the regulatory discourse was dominated by the efforts to properly regulate the shadow banking sector and the European Commission explicitly outlined MMFs and ABCP conduits as possible shadow banking activities/entities (EC 2012b). Alongside its "on-going work on shadow banking", the European Commission launched a consultation on Undertakings for Collective Investments in Transferable Securities (UCITS) focusing on "the role of money market funds in the

\footnotetext{
10 Regulation (EU) 2017/2402 of the European Parliament and of the Council of 12 December 2017 OJ L 347, 28.12.2017, p. 35-80; https://eur-lex.europa.eu/legal-content/en/TXT/?uri=CELEX:32017R2402 and Regulation (EU) 2017/2401 of the European Parliament and of the Council of 12 December 2017 OJ L 347, 28.12.2017, p. 134; https://eur-lex.europa.eu/legal-content/en/TXT/?uri=CELEX:32017R2401.
} 
management of liquidity for investors, their engagement in the securities lending and repo markets as well as their systemic involvement in the overall financial marketplace" (EC 2012a). Similar concerns were shared by the European Parliament, which besides recognizing MMFs' role in funding financial institutions invited the European Commission to take additional measures regarding these funds, in particular a limited-purpose banking license, capital and other prudential requirements (EP 2012).

While already at this early stage it was recognized that "some elements that fall under the term [Shadow Banking] are vital for financing the real economy" (ibid: 2), neither the European Parliament nor the European Commission openly connected the MMFs or ABCPs to the well-being of the real economy. Rather in terms of MMFs, regulatory efforts intensified with ESMA constantly working on requirements for $\mathrm{MMFs}^{11}$ and the European Commission designing a European regulation for MMFs. In context of the latter the European Systemic Risk Board (ESRB) published a report with recommendations (ESRB 2012) that were "intended to complement the MMF reforms advocated by the Financial Stability Board and IOSCO" (Lexology 2013). These reform efforts mainly focused on the constant net asset value (CNAV) sector which constitutes those parts of MMFs which are structured like bank deposit accounts. ${ }^{12}$ At the same time, they are also the forms of MMFs investing in private short-term debt and constituting the major investors in the ABCP market. These characteristics were addressed by the initial proposal of the European Commission which came later than initially planned and was announced as just another part of the existing framework (UCITS) (Lexology 2013).

The proposed capital buffers were not as harsh as the mandatory move to variable net asset value proposed by the ESRB, but were still criticized as a deathblow to CNAV fund industry, which constitutes almost half of the European MMF market (DB Research 2015). In addition to this trenchant critique of the MMFR proposal, there was a broader criticism that outlined the European Commission's latest work as being 'schizophrenic on shadow banking', arguing that punitive regulatory treatment eliminating CNAVs stands against the goal to promote alternative sources of long-term financing (Euromoney 2013). Meanwhile the European Commission also proposed initiatives "to foster the supply of long-term financing" and "to improve and diversify the system of financial intermediation for long-term investment in Europe" (EC 2013). Thus, we see how in the broader context two discourses clashed with each other, the push for a harsher regulation on shadow banking institutions, favoured by the responsible Commissioner Michel Barnier, and that involving growth enhancement through supporting debt channels outside the banking sector. These, as was argued by Draghi (2014) and Langfield and Pagano (2016) were necessary, as the European financial system was too bank-based,

\footnotetext{
${ }^{11}$ At the end of 2012 ESMA updated its UCITS framework and in beginning of 2013 it updated its recommendations for MMFs.

${ }^{12}$ They promise investors to pay constantly $1 \$$ per share.
} 
posing unnecessarily high systemic risks to the Eurozone economy.$^{13}$ In a similar vein, the European Commission already started to consider ways to enhance new finance channels for the real economy in the end of 2012 (Interview 7) which then finally culminated in its initiative of long-term finance in 2014 (EC 2014).

Notwithstanding that $\mathrm{ABCPs}$ and securitization vehicles more broadly were also considered possible shadow banking entities by the European Commission at the beginning of 2012 (EC 2012b), they soon took a different route than MMFs. This started in 2012 when representatives of the Association for Financial Markets in Europe (AFME) approached the European Commission to consider the high quality of a reasonable part of European securitization and the possibility to distinguish them from more lowquality products (Interview 12). Subsequently, the European Commission started a review of the capital requirements regulation ${ }^{14}$ and the Solvency II directive ${ }^{15}$ arguing that during its drafting it "was conceived in a better economic environment" (Lexology 2012). EIOPAs report on long-term financing thereupon proposed changes to capital requirements and advised "different risk charges for securitizations with higher and lower risk profiles" (EIOPA 2013: 1). At the same time a High-Level Expert Group (HLEG) chaired by Alberto Giovannini demanded that "national and European policymakers to issue clear supporting statements about the important role securitization has to play in financing the real economy" and invited them to consider "labelling initiatives established by the financial industry" (HLEG 2013: VII). ${ }^{16}$

Alongside its assessment of the discrimination of securitization in general the HLEG also found that "the treatment of back-up liquidity lines provided to ABCP vehicles is at best unclear and at worst heavily penalizing transactions that have provided over time and successfully an effective answer to corporate in search of working capital funding solutions (among other objectives) to corporates" (HLEG 2013: 47). ${ }^{17}$ Towards the end of this first phase, the work on a re-labelling of securitization intensified and European regulators pushed the new regulatory measure to the international level, initiating work

\footnotetext{
${ }^{13}$ However, as a paper by Giovannini et al stated in 2015 "it is far from clear that the source of the investment deficit is the financial system; it could equally well be low demand for capital rather than insufficient supply of finance" (p. 1).

${ }^{14}$ Regulation (EU) No 575/2013 of the European Parliament and of the Council of 26 June 2013 on prudential requirements for credit institutions and investment firms and amending Regulation (EU) No 648/2012 (CRR), OJ L 176, 27.6.2013, p. 1; https://eur-lex.europa.eu/legal-content/EN/TXT/PDF/?uri=CELEX:32013R0575\&from=en.

${ }^{15}$ Directive 2009/138/EC of the European Parliament and of the Council of 25 November 2009 on the taking-up and pursuit of the business of Insurance and Reinsurance (Solvency II), OJ L 335, 17.12.2009, p.1; https://eurlex.europa.eu/legal-content/EN/TXT/PDF/?uri=CELEX:32009L0138\&from=EN.

${ }^{16}$ This development vindicated industry views, which already immediately after the crisis had insisted on the need for securitization (Interview 1)

${ }^{17}$ These impediments have effectively ended the shadow banking chain in the US, where due to high regulatory costs $A B C P$ is no longer a viable channel for credit, merely being used for liquidity diversification of banks (interview 4, 5).
} 
by the IOSCO and FSB. ${ }^{18}$ Nevertheless, these efforts almost solely focused on term-securitization which are considerably different from their short-term counterparts, $A B C P s$, thus requiring a different regulatory treatment. A fact that regulators had to learn from the industry during the second phase. ${ }^{19}$ Another important fact they had to learn about was the high dependence of the ABCP market upon the MMF industry as major investor. The industry already outlined this in 2013 stating that "MMFs represent approximately 50\% of all investments in Asset Backed Commercial Paper ( $A B C P$ ) in Europe" (IMMFA 2013: i). In addition to that, the direct link between them was underlined: "MMFR will reduce funding of banks by MMF and impact "ABCP, a key and growing source of market funding for European companies" (IMMFA 2013: iii). But at that point of time, regulators were still caught in their struggle to line up their approach to regulate shadow banking with the new attempt to find a 'regulatory fix' for the real economy debt. With the coordination of different regulatory approaches in its infancy, the European Commission's MMFR proposal did not take into account the interdependence of MMFs and $A B C P s$, an inaccuracy that was to be addressed during the second phase, alongside with the growing awareness of regulators of potential unintended consequences of their market interventions.

All in all, during this first phase regulators were still on the same page regarding their strategies to cope with the financial fragilities caused by the newly discovered financial institutions outside the realm of regular banks. Throughout the preparation of the European Commission's MMFR proposal efforts were aligned with the European Parliament, focusing on a bank-like regulation for those parts of the MMF industry. ${ }^{20}$ Thus, the coordination within the rule-making network, between the legislative agents worked out smoothly, while the private agents were still largely excluded. Even though, MMF managers advised their clients to "keep calm and carry on" they also were "disappointed with a number of the regulatory proposals" (HSBC 2013). However, these disappointments were not only about additional requirements, like capital buffers, but also about some that have not been formalized, like liquidity fees (ibid: 2). This assessment already points to the transformation of the mode of regulation within the policy network, happening during this period, focusing on 'how' to design reforms and not 'if' they were going to happen (Dorn 2016). This becomes even more obvious when looking at the occurrence of the newly designed securitization regulation and the status of $A B C P S$ within it. Here private agents were knocking on open doors and have been taken seriously by regulators while being part of the drafting right from the beginning (Interview 6, 7). Nevertheless, in terms of a revival of securitization, regulators were cautious to publicly approach this issue, being

\footnotetext{
18 This effort was perceived by US regulators as an act of „regulatory forbearance "for their banking industry on the part of EU regulators (interview 3).

${ }^{19}$ These developments vindicated industry views, which already immediately after the crisis had insisted on the need for securitization (interview 1) and replicated a pattern, where policy makers were sensitive to credit provision for the real economy (for the German case, interview 2)

${ }^{20}$ That is to say, MMFs which engage in maturity transformation of privately issued debt.
} 
aware of countervailing public discourses. This also points to the still covert relationship between the rule-making network and private actors.

In light of this, it seems that the roots of the reconsideration of the financial system lie here. The schizophrenia on shadow banking fully unfolds its effects with regulators pursuing projects that are contradicting each other while not considering their mutual effects. Proceeding from this assessment, the following phase shows how regulators became more knowledgeable about these contradictory effects. While learning that a complete shutdown of the CNAV funds would have some severe implications for financial institutions depending on them for short-term funding, they also started to acknowledge the particularities of $A B C P s$ and their dependence on MMFs for their financing. Therefore, they chose a more lenient approach on MMFs and also adapted the framework for simple, transparent and standardised (STS) securitisations to the idiosyncrasy of ABCPs against the backdrop of their high importance for the real economy. Nevertheless, this also shows the ironic turn of regulators' schizophrenia: While trying to regulate the shadow banking sector, they learn how the new regulatory burden on the regular banks and the low yield environment pushes market actors in exactly these markets. This causes them to rethink their strategies of coping with the new face of finance and subsequently effects the coordination within the policy network.

\section{Second Phase (2014-2016) Expanding the spectrum}

During this second phase regulators expanded their spectrum of considerations, in other terms they get 'more knowledgeable' about the interlinkages within the financial system and they attempt to gain "a clearer understanding of the interaction of the individual rules and cumulative impact of the legislation as a whole including potential overlaps, inconsistencies and gaps" ${ }^{21}$ (EC 2015). Furthermore during this time, the broader discourses on the need for growth as the primary goal fully unfold their effects on the policy network, emphasising the underdevelopment of the European financial system and the downsides of its 'overbankedness' (e.g. Pagano et al 2014, Langfield and Pagano 2016). The potential adverse effects of inconsistencies in the regulatory infrastructure on MMF and ABCP let them adapt the proposals towards prevailing market structures. However, the complexity of the two subjects at hand hampered the coordination within the rule-making network and is thus a decisive explanatory factor for the diverging negotiation stances in the end. While the MMFR is substantially modified, the STS regulation is opened up to appreciate the particularities of ABCPs in contrast to term securitization. Apart from that, in according more importance to these institution's role as channel for

\footnotetext{
${ }^{21}$ This for example let the Commission to publish a call for evidence on the EU regulatory framework for financial services that aimed at analyzing "Rules affecting the ability of the economy to finance itself and growth; Unnecessary regulatory burdens; Interactions, inconsistencies and gaps; Rules giving rise to unintended consequences" (EC 2015).
} 
real economy debt, regulators also started to acknowledge the importance of their deeply intertwined relation.

Regarding the drafting of the securitization regulation, the second phase brought more and more into limelight what so far was rather happening in the backstage area. In the beginning of 2014 the Committee on Economic and Monetary Affairs (ECON) officially called for the development of a definition of high-quality securitization (ECON 2014: 8). Around the same time the European Commission sent a call for advice to the European Banking Authority (EBA) to "assess the appropriateness, from a prudential perspective, of granting future preferential treatment to certain securitisation transactions qualified as 'high quality' transactions in order to foster EU securitisation markets" (EBA 2015: 2). It took the EBA almost a year to finish its report on securitization, due to the extensive efforts undertaken to design the recommendations right which included public consultation, numerous meetings and workshops with industry representatives (Interview 7, 11). The extensive work on securitization led also to a growing awareness of $A B C P^{\prime}$ s particularities in contrast to termsecuritization.

After the Bank of England and the ECB noted the unique aspects of ABCP (ECB/BoE 2015: 3), also the European Commission's public consultation on an STS framework notes that "due to the specificities and different structures of short-term instruments (...), a number of the criteria set out in the delegated acts cannot be directly applied" to ABCP and further underlines that "these instruments are important refinancing tools for non-financial companies" (EC 2015: 7-8). In what followed, the EBA continuously worked on defining a "'qualifying' framework for term securitisations adapted to recognise many specificities of the ABCP segment" (EBA 2015: 7). This happened in a co-productive manner together with representatives of the industry (Interview 7). In July 2015 it then fully accounted for ABCP and stressed that its "current market is almost exclusively focused on real-economy-related exposures mostly financed by multi-seller conduits" (EBA 2015: 16). Consequently, only two months later the European Commission publishes its proposal dedicating a special section to ABCP (Interview 6, 8). But notwithstanding the extensive efforts undertaken to strike the right balance between sustaining status quo and undertaking some cosmetic procedures (Interview 8), the proposal was dismissed as deathblow to the ABCP market (TSI 2015, interview 11).

However, after a period of highly intensive coordination work in the policy network, the European Council's negotiation stance (even though designed in record time ${ }^{22}$ ) left some space for improvement in terms of underlying maturities. A requirement for which EBA was already criticized (Fitch 2015). Nevertheless, the need to revise and clarify the criteria for $A B C P$ remained, given that "without reviving

\footnotetext{
${ }^{22}$ The Council only took two months to define its negotiation stance which was welcomed by Commissioner Hill in a tweet as "Our securitisation proposals agreed at record speed" (Jonathan Hill, 2. December 2015).
} 
the ABCP market (...) any attempt to support SME financing in Europe is surely doomed to fail" (Whitecase 2016). Meanwhile the European Parliament's work has been subject to some internal wrangling and considerations focused on ABCPs' particularities. Thus, one of the first drafts by the ECON required a 1-year Weighted Average Lifetime (WAL) instead of 2 years ${ }^{23}$ and a $20 \%$ risk retention instead of $5 \%$, but therefore saw no need for a complete ban on re-securitization (one of the more sensitive topics), given that to their knowledge markets worked well with 5\% (Interview 8). Accordingly, while regulators certainly converged in several topics and agreed upon the need to grant $A B C P$ specified leeway, serious differences remained in their design. This reflects the fact that in coping with technicalities regulators relied on different experts thus holding different views while generally pursuing the same goal, which was particularly acute in the European Parliament. ${ }^{24}$ Thus, we find contradictory dynamics, stemming from factors enabling and those inhibiting coordination within the rule-making network.

In terms of the MMFR, at first the economic interest of the markets' well-being stood against the general interest of financial stability, making the negotiations extremely difficult which was overcome by the shifting discourses and the new mode of regulation. Most importantly the Council designed the Low-Volatility Net Asset Value Fund (LVNAV). This new category was evaluated by the industry as not being inherently different to the original CNAV models and assessed as likely to allow CNAVs to survive in parallel to VNAV funds (Pension \& Investment 2016). This is a good example of how actors within the rule-making network finally coordinated their efforts because even though designed by the European Council, the European Parliament was the first to mention the LVNAV funds in their negotiation stance (Interview 12,13). While in the beginning of 2015, the European Parliament still adhered to a similarly strict negotiation stance as the European Commission in its initial proposal, a definite turning point to this strategy was the rejection of its own amendments (e.g. capital buffers) in April 2015. According to its own research service "the proposed amendments would therefore retain the effect of the European Commission's proposals to largely end the use of constant net asset value in the European MMF industry" (EPRS 2015: 7). Even more, the European Parliament required the European Commission to adopt criteria for STS consistent with Solvency II, which "should take into account the specific characteristics of securitisations with maturities at issuance of less than 397 days" (EP 2015: 6).

The $A B C P$ industry welcomed the acknowledgement of the importance of $A B C P$ s given that they already uttered concerns about the restriction of CNAV in 2014 stating that "a vibrant ABCP market

\footnotetext{
${ }^{23}$ As outlined in the primer of section four, $A B C P$ s are sensitive towards such regulatory changes in the allowed maturity, given that their profitability depends on the yield spreads.

${ }^{24} \mathrm{An}$ interviewee pointed out that the European Parliament was a particular heterogeneous group of actors which seek advice from widely varying resources, e.g. the movie director of 'the big short' (Interview 12).
} 
(...) is not achievable without CNAV MMFs. This is because CNAV MMFs own approximately $70 \%$ of outstanding ABCP in Europe (as at June 2014)" (IMMFA 2014: 11). At this point the interconnectedness between MMFs and ABCPs fully unfolds its complexity upon regulatory coordination which then fed into the drafting of the MMFR, a fact certainly perceived positively by the industry (Interview 11). As a reaction to the take-up of their concerns, Moody's first combined MMF and ABCP conference took place in 2016. It closed "on a positive note, with all speakers cautiously optimistic that the inclusion of $A B C P$ in the STS considerations of the EU regulation, together with the focus of remaining issuers on financing the "real" economy, will help continue the slight growth in multi-seller and repo conduit outstandings witnessed over the last few years, thereby also continuously providing MMFs with more investment alternatives" (PCU 2016).

Most notably, the industry argumentation not only overwhelmingly relies upon the importance for real economy finance but also takes up the more and more prominent argument of Europe's financial system as being overbanked. Since the beginning, they became not weary to emphasize the importance of MMFs for ABCPs and the latter's for the economy. The European Banking Federation (EBF) commented already in 2013 on the MMFR that "the eligible pool of underlying assets should be broadened to capture other instruments in order to continue allowing this type of funding stream to the wider economy" (EBF 2013: 1). This also reflects the broader debates dominated by the importance of real economy finance and alternative credit channels next to the banking system, as the following quote perfectly demonstrates: "ABCP improves the working capital of large companies such as Telecom Italia, Lafarge and Volkswagen. However, over $50 \%$ of the recipients of this funding are small and medium-sized enterprises (SMEs) and non-rated firms that have limited direct access to capital markets, particularly in countries where banks are finding it increasingly difficult to lend to such firms" (IMMFA 2013: i). These discourses influenced the work in the policy network on the MMFR and in order to not cut the major funding source of $A B C P$, less stringent criteria were considered within the Council and the European Parliament (Interview 8) granting a special status within the eligible asset criteria in their negotiation stances (EP 2015, Council 2016). In particular, they referred to those ABCPs "where the underlying assets were associated with supporting the working capital of manufacturers and the sales of real economy goods and services" (EP 2015: 6).

It appears that during the second phase the broader discourses affected the outlook of the rule-making network and that as long as the financial activities under scrutiny enable the channelling of debt into the real economy, the design of the regulations should sustain its orderly flow while providing only for minor safety improvements. With this new perspective, regulators became more knowledgeable about the mutual effects of the regulatory reforms and started to endorse MMFs so that they can remain investors of $A B C P s$ while acknowledging that $A B C P$ s should be seen separately from term- 
securitization (Interview 12). But even though the ultimate aim was aligned, the particular strategies differed given that the multifaceted nature of these financial products does not allow for a uniform approach towards its regulation. Thus, while the European Parliament as well as the Council still restrict the amount of eligible securitization to $15 \%$, the acknowledgement of $A B C P$ s particularities was of special interest to the Council (Lexology 2016). Therefore, in an act of cohabitation, they drew on the expertise of stakeholders which noted that "the efforts made by the regulators to better understand the market" were "encouraging" (Freshfields 2016: 4). However, to formulate regulatory measures through reconciling different standpoints the policy network needs a certain stability of resources. Drawing on different sources of knowledge regulatory initiatives diverged to a considerable degree, albeit pursuing similar strategies aligned in the goal to provide a regulatory fix for real economy debt (Fernandez and Wigger 2016). Coordinating these different positions during the third phase, regulators' insecurity about the technical refinement led them to play it safe, consequently designing exhaustive regulations.

\section{Third Phase (2016-2017) The devil lies in the detail}

In this last phase, regulators try to reconcile their differences and openly pursue the strategy of designing a European regulatory infrastructure that sustains the MMF and $A B C P$ industry for the sake of preserving it as transmission mechanism of debt into the real economy, while providing the appropriate rules to guard against market downturns (Council 2017). In their effort to cultivate markets to this effect, they rely upon the expertise of market actors, while simultaneously having to cope with a highly politicised reform process. Thus, in the attempt to align their different viewpoints on the design of the regulatory reforms with the political agenda, they could not co-articulate the compromise with private agents but were thrown back onto themselves. That is to say that final Trilogue negotiations exclusively take place within the rule-making network, excluding private actors by and large. Par consequent, even though public and private actors come together "in strategic terms" (Dorn 2016: 101), they are separated again through institutional restrictions. Thus, in the end in trying to keep up with the reality of markets "regulators worked out quite well the advantages of MMF", while in the details they did not make such a good job that is where it became overly politicized and culminating in a rather "perverse result" (Interview 12). Regarding ABCPs, the regulatory refinement also implied adverse results with the estimated impact that less than half of ABCPs will gain the STS label and even less of the transactions (Interview 11).

Under "a lot of political pressure to close the file" (Pensions \& Investments 2016), the MMFR Trilogue negotiations came to end in the mid of 2017 bringing together "elements of oversight which have previously been afforded not just by the previous regulations, but also by industry codes of praxis, rating agency requirements and prudent practices" (Treasury Today 2017). Just like an industry 
representative forecasted in 2016, the few requirements that were unworkable had been largely removed in the process (Pensions \& Investments 2016). With the design of the LVNAV funds, regulators had picked up the current market sentiments and "those going down the LVNAV route should continue to operate in a similar manner as they currently do as they used to do, which means there will hopefully not be too much disruption to the industry" (Treasury Today 2017). Even more, the MMFR is also considered to set the right framework to overcome current negative market dynamics. As another industry representative put it "the LVNAV model has addressed the need for greater transparency, higher liquidity and for different type of product due to the fragmentation of investors in Europe and the breadth of jurisdictions they operate in" (Pension and Investment 2016).

This indicates in how far regulators have been successful, at least from their point of view, aiming at providing for an appropriate regulatory infrastructure for MMFs to continue, while seeking to ensure them against downturns and describing the final MMFR as "a regulation to ensure the smooth operation of the short-term financing market" (Council 2017). To a certain extent, this assessment is shared by the industry contemplating that "while the changes may seem quite dramatic on paper, what the regulations have brought about is a coping mechanism for funds to be able to continue operating in times of market stress" (Treasury Today 2017). However, even though the main requirements are designed in an appropriate manner, when it comes to the future impact of the MMFR it might be that "the devil lies in the detail" (Interview 12). Accordingly, there remains a certain danger that the compliance costs to the MMFR are too high for smaller funds leading to a further concentration within the market (Interview 12). This lies neither in the intention of the regulators nor that of the industry and shows regulators' difficulty to act on a politicized topic, pressured to finalize negotiations while trying to get its design right.

In terms of the STS regulation ${ }^{25}$, the Trilogue negotiations brought the ABCP requirements a good term closer to fit the prevailing market structures. On the one hand, the risk retention requirement was lowered as requested by the European Parliament, which fit the European Commission's point of view (Interview 8). On the other hand, the re-securitization ban was lifted for ABCPs which was very important for $A B C P$ issuers. Again, here the understanding of regulators of this technique widely varied: in $A B C P$ programs there is a difference between the tranching on the seller level and that of the program level, which was confusingly labelled alike but has some significant differences in terms

\footnotetext{
${ }^{25}$ Regulation (EU) 2017/2402 of the European Parliament and of the Council of 12 December 2017 laying down a general framework for securitisation and creating a specific framework for simple, transparent and standardised securitisation, and amending Directives 2009/65/EC, 2009/138/EC and 2011/61/EU and Regulations (EC) No 1060/2009 and (EU) No 648/2012, OJ L 347, p. 35; https://eur-lex.europa.eu/legalcontent/EN/TXT/PDF/?uri=CELEX:32013R0575\&from=en.
} 
of risk. ${ }^{26}$ Another important change was the switch in the hierarchy of approaches, which was introduced during the Trilogue negotiations and aimed at reducing the impact of credit rating agencies' ratings on capital requirements for term-securitization. This decision, however, is very likely to lead to significantly higher capital charges for ABCPs, independent of their STS status (Interview 7, 11). Overall, the intense work of coordinating and designing with private actors was only partially successful in the end, in so far as these requirements still are very likely to impose a regulatory burden on market actors too high to continue this low margin business (Interview 11). Thus, notwithstanding the general considerations that the ABCP market performed reasonably well after the crisis, in the end the fear to give $A B C P$ s too much leeway and thus enabling their misuse for arbitrage purposes inhibited regulators in a way that let them favour a tougher approach (Interview 11).

Regarding the shadow banking chain itself, some considerable changes have been undertaken to $A B C P$ s to sustain them as eligible investments for MMFs. First, the refinement already undertaken by the Council was broadened, leading to an expansion of ABCPs eligible for investment. While augmenting the initially proposed $15 \%$ to $20 \%$ STS ABCPs, it also seems that regulators anticipated potential problems in the labelling process. Furthermore, regulators agreed on the deletion of the 397 days restriction of their weighted average lifetime "due to the particular nature of the underlying assets for some securitisations and ABCPs" (EP and Council 2017: 6). Thus, they provided the regulatory structure, allowing the MMFs to remain the main investors in the ABCP market, setting the limits for length even high above their current portfolio composition. In this sense, the final shape of the MMFR is advantageous for ABCPs, granting MMFs considerable leeway to invest in these products, going even beyond their current engagement. However, considering that the future of the ABCP market itself is at best unclear, it might be that the intention to preserve the shadow banking chain for the sake of an orderly flow of debt into the real economy might be inhibited by exactly those same efforts.

All in all, in this final phase regulators aimed at refining the existing regulatory provisions, e.g. liquidity baskets and suspension of redemption for MMFs (Fitch 2016) and liquidity mismatches in ABCP programs (Interview 8). However, on the one hand, the coordination among public agents were complicated by high technical complexity and the different sources of knowledge they drew upon, while on the other hand, the broader discourses demanded a regulatory design that supports real economy financing through supposedly non-bank channels. Under the pressure to ensure a timely drafting but also an appropriate design satisfying all actors, regulators had to cope with the highly politicized negotiations against the backdrop of the broader discourses demanding growth. While being fully aware that these regulations were interconnected, and possible inconsistencies might

\footnotetext{
${ }^{26}$ In ABCP transactions, the end client provides over-collateralization in order to ensure that the ABCP conduit itself has no costs from defaults, which leads to a form of re-securitization, but which has nothing to do with resecuritization of ABS seen before the crisis.
} 
trigger negative effects in related markets, they aimed at sustaining the relationship of MMFs and $A B C P s$. But because their understanding of the actual technicalities varied widely and the negotiations themselves were highly politicized, they created a regulatory framework of which the future impact remains unclear. This must be seen in light of the development between the rule-making network and private actors, which after being largely kept outside in the first phase have been invited to coformulate regulation in the second phase but are excluded from the final negotiations due to formalized rules. Thus, being thrown back on themselves, regulators attempted to play it safe which complicated the regulatory design even further.

\section{Conclusion}

This paper set out to outline the agency of European regulators in reviving the relationship between the regular banking system and key shadow banking institutions for the sake of providing a channel for the orderly flow of real economy debt. By analyzing the drafting periods of the MMFR and the ABCP regulation from 2012 to 2017 we delineated the importance of the interplay between broader structural phenomena and the institutional setting for the constitution of this regulatory agency. On one hand, the structural setting was characterized by the prioritization of growth enhancing measures (Endrejat and Thiemann 2018) and the reassessment of the financial sector as central to the well-being of the real economy, expressed most prominently in the financial underdevelopment hypothesis (Langfield and Pagano 2016). On the other hand, the shift in political power configurations to the benefit of European regulators (Falkner 2016) enabled them to use the bounded discretion in their institutional environment to rise from being the transmission belt between international and national level of regulation (Quaglia 2015) to form an own agency. This allowed for notable changes within the policy network were regulators discovered the distinctiveness of European financial markets and invited private agents to discuss an appropriate regulatory design (Dorn 2016). By analyzing the case of $M M F$ and $A B C P$ regulation we have shown that this was not an act of regulatory capture but that this evolved out of the new strategy of European regulators to cope with the highly complex subject at hands.

At the beginning, from 2012 to 2014, regulatory considerations were characterized by a schizophrenia on shadow banking (Euromoney 2013). They adhered to the goal to stabilize financial markets but also increasingly recognized the need for growth through an orderly working financial system. The policy network was characterized by the understanding of the necessity to regulate, which started to change towards a critical view on its design itself. Departing from this, private actors got increasingly included in regulations drafting. Therefore, regulators became more conscious of adverse impacts of intended reforms which laid the cornerstones of the formation of a new regulatory agency opening up to the 
expertise of market actors. The second phase from 2014 to 2016 was defined by the prominence of discourses stressing the underdevelopment of the European financial system and its 'overbankedness' (Pagano et al 2014), while lacking growth increasingly became a problem to stability (Langfield and Pagano 2016). To better cope with the intricacies of the financial system regulators expand their spectrum and grant private actors a new status within the policy network (Dorn 2016) while they become knowledgeable, trying to grasp the whole interdependencies of the several parts of the financial market and to design regulations accordingly. Notwithstanding these efforts, during the final phase in 2017, in attempting to settle the Trilogue negotiations regulators had to cope with the high politicization of the topics and had difficulties to align their standpoints in a way that allows for the smooth operation of MMFs and ABCPs. Because the Trilogues only take place within the rule-making network excluding private agents, they were "thrown back on themselves" negotiating without the possibility to properly consult sources of knowledge from the industry. In the end regulators were playing it safe because they were too afraid of giving too much discretion to market participants and allowing for arbitrage. Consequently, the effects of the regulation are defined by the high detailedness with potential adverse effects on the markets (Interview 7, 11, 12).

On the one hand, the $A B C P$ industry laments that the final regulations are not in accordance with the market realities due to regulators inability to fully understand the instrument (TSI 2017), estimating that only few $A B C P$ transactions and none of the programs will be able of attaining the $A B C P$ status (Interview 6, 7, 11). On the other hand, the MMF industry slightly shares these mixed feelings, because even though a lot of the requirements fit the industry's structures, "the devil lies in the details" (Interview 12). How to make sense of these mixed results in terms of our theoretical approach? After the reassessment of the financial system and the embracement of its key features by European regulators designing an appropriate network of regulation with the help of private actors, the diversity of regulators negotiation stances fully outplayed on the design. Thus, the explanatory variable is to be found on the institutional level, where coordination hinges upon the stability of actors and resources (Peterson 2003). Consequently, the different regulatory actors formulated different viewpoints, a problem for coordination which was further exacerbated by the high technicality of the problem and the polarization of the reform process.

In this paper we aimed at analysing the factors that drove European financial market regulation within the last years and to figure out what shaped and constrained their market interventions. In analyzing the regulatory treatment of the shadow banking chain and its single parts the paper demonstrated the active role of regulatory agency in the reconstruction of the shadow banking system after the crisis. Throughout the three phases of the $A B C P$ and MMF regulation it can be seen how the discourse transformed from clamping down on shadow banking to transforming shadow banking into resilient 
market-based finance. Notwithstanding their endeavours to fully understand these financial institutions, the inherent technical complexity hampered the finetuning of the two reforms. These attempts were further compounded by the politically delicate topics themselves. The problem at hand is the dilemma of regulators to manoeuvre such intricate technical subjects against the backdrop of pertinent political discourses. Accordingly, the difficulties lie in the details of the reforms and the predicament to identify credible sources of knowledge. In light of the anniversary of the financial crisis, it is worth questioning if the current set-up of the hidden, last minute use of only certain industry representatives' knowledge is the optimal set-up. 


\section{References}

Acharya, V. V. \& Schnabl, P. (2010). 'Do global banks spread global imbalances? Asset-backed commercial paper during the financial crisis of 2007-09'. IMF Economic Review, 58(1), 37-73.

Archer, M. S. (2003). Structure, agency and the internal conversation. Cambridge University Press.

Baklanova, V. \& Tanega, J. (2018), 'European money market funds', in Nesvetailova, A. (Eds.), Shadow Banking: Scope, Origins and Theories. London: Routledge.

Bell, S. (2011). 'Do We Really Need a New 'Constructivist Institutionalism' to Explain Institutional Change?', British Journal of Political Science, 41(4), 883-906.

Bell, S. \& Hindmoor, A. (2015a). Masters of the Universe, Slaves of the Market. Harvard University Press.

Bell, S. \& Hindmoor, A. (2015b). 'Masters of the Universe but Slaves of the Market: Bankers and the Great Financial Meltdown', The British Journal of Politics and International Relations, 17(1), 1-22.

Boyer, R. (2000). 'Is a finance-led growth regime a viable alternative to Fordism? A preliminary analysis'. Economy and society, 29(1), 111-145.

Braun, B. (2018). 'Central banking and the infrastructural power of finance: the case of ECB support for repo and securitization markets'. Socio-Economic Review, https://doi.org/10.1093/ser/mwy008.

Braun, B. \& Hübner, M. (2017). 'Fiscal fault, financial fix? Capital Markets Union and the quest for macroeconomic stabilization in the euro area'. Competition \& Change, doi: $10.1177 / 1024529417753555$

Braun, B., Gabor, D. \& Hübner, M. (2018). 'Governing through financial markets: Towards a critical political economy of Capital Markets Union'. Competition \& Change, DOI: 1024529418759476.

Braun, B. (2016). 'Speaking to the People? Money, Trust, and Central Bank Legitimacy in the Age of Quantitative Easing'. Review of International Political Economy, 23(6), 1064-1092.

Committee on Economic and Monetary Affairs (ECON) (2014). 'Report on Long-Term Financing of the European Economy (2013/2175(INI))'. European Parliament: Strasbourg.

Deutsche Bank (DB) Research (2015). 'Money market funds - an economic perspective- Matching short-term investment and funding needs'. February 2015, Deutsche Bank: Frankfurt am Main.

Dorn, N. (2016). 'Capital cohabitation: EU Capital Markets Union as public and private co-regulation'. Capital Markets Law Journal, 11(1), 84-102.

Draghi, M. (2014). 'Mario Draghi: Hearing at the Committee on Economic and Monetary Affairs of the European Parliament'. 17 November 2014, European Parliament: Strasbourg.

$\mathrm{ECB} / \mathrm{BOE}$ (2015). Joint Response from the ECB and the BOE to the Consultation Document of the EC: 'An EU Framework for Simple, Transparent and Standardized Securitisation'. available online: https://www.ecb.europa.eu/pub/pdf/other/ecbboe_response_ec_consultation_on_securitisation20 150327.en.pdf (last accessed 11.10.2017).

Endrejat, V. \& M. Thiemann (2018). 'Balancing Market Liquidity: Bank Structural Reform Caught Between Growth and Stability'. Journal of Economic Policy Reform (forthcoming).

Engelen, E. (2015). 'How Shadow Banking became Non-Bank Finance: Blame the Conjuncture'. Unpublished manuscript, University of Amsterdam. 
Euromoney (2013). 'European Commission Schizophrenic on Shadow Banking, 23 September 2013'. available online https://www.euromoney.com/article/b12kjshr4vz2gn/european-commissionschizophrenic-on-shadow-banking (last accessed 18.10.2017).

European Banking Authority (EBA) (2015). 'EBA Technical Advice on Qualifying Securitisation - Public Hearing Event'. 26 June 2015, EBA: London.

European Banking Federation (EBF) (2013). 'EBF position on the Money Market Funds Regulation'. available online: http://www.ebf-fbe.eu/uploads/EBF_005237\%20\%20\%20EBF\%20position\%20paper\%20on\%20MMFs\%20.pdf (last accessed 21.03.2018).

European Commission (EC) (2012a). 'Taking action on shadow banking: avoiding new sources of risk in the financial sector- Press Release'. March 2012, European Commission: Brussels.

European Commission (EC) (2012b). 'Green Paper on shadow banking'. March 2012, European Commission: Brussels.

European Commission (EC) (2013b). 'Press Release: European Commission launches Green Paper on the long-term financing of the European economy'. 25 March 2013, European Commission: Brussels.

European Commission (EC) (2014). 'Communication on long-term financing of the European economy: frequently asked questions'. March 2014, European Commission: Brussels.

European Commission (EC) (2015). 'Call for evidence: EU regulatory framework for financial services'. 30 September 2015, European Commission: Brussels.

European Council (Council) (2016). 'Proposal for a REGULATION OF THE EUROPEAN PARLIAMENT AND OF THE COUNCIL on Money Market Funds - Presidency compromise'. 10 May 2016, Council of the European Union: Brussels.

European Council (Council) (2017). 'Press Release: Money market fund rules adopted'. 16 May 2017, Council of the European Union: Brussels.

European Insurance and Occupational Pensions Authority (EIOPA) (2013). 'EIOPA Proposes Changes to Capital Requirements for Debt Securitisation'. 19 December 2013, EIOPA: Frankfurt.

European Parliament (EP) (2012). 'Shadow banking European Parliament resolution'. 20 November 2012, European Parliament: Strasbourg.

European Parliament (EP) (2015). 'Amendments adopted by the European Parliament on 29 April 2015 on the proposal for a regulation of the European Parliament and of the Council on Money Market Funds'. available online http://www.europarl.europa.eu/sides/getDoc.do?pubRef=//EP//NONSGML+TA+P8-TA-2015-0170+0+DOC+PDF+V0//EN (last accessed 21.03.2018).

European Parliamentary Research Services (EPRS) (2015). 'Money Market Funds: Impact Assessment of Substantive EP Amendments'. European Parliamentary Research Service: Brussels.

European Systemic Risk Board (ESRB) (2012). 'Recommendation of the European Systemic Risk Board of 20 December 2012 on money market funds (ESRB 2012/01)'. ESRB: Frankfurt.

Falkner, G. (2016). 'The EU's Current Crisis and Its Policy Effects: Research Design and Comparative Findings'. Journal of European Integration, 38(3), 219-235.

Fernandez, R. \& Wigger, A. (2016). 'Lehman Brothers in the Dutch offshore financial center: the role of shadow banking in increasing leverage and facilitating debt'. Economy and Society, 45(3-4), 407-430. 
Fitch (2015). 'One year cap would affect over half of ABCP-funded assets'. 31 July 2015, Fitch Ratings: London.

Fitch (2016). 'Report: Standard VNAV MMFs Gain Momentum - Diverse Investment Strategies Challenge Market Segment Understanding'. September 2016, Fitch Ratings: Paris, London.

Freshfields (2015). 'ABCP, the proposed EU securitisation regulation and the real economy'. November 2015, Freshfields Bruckhaus Deringer: London.

Funk, R. J. \& Hirschman, D. (2014). ,Derivatives and deregulation: Financial innovation and the demise of Glass-Steagall'. Administrative science quarterly, 59(4), 669-704.

Gabor, D. (2016). 'A step too far? The European financial transactions tax on shadow banking'. Journal of European Public Policy, 23(6), 25-945.

Gabor, D. \& Ban, C. (2016). 'Banking on Bonds: On the New Links between States and Markets'. Journal of Common Market Studies, 54(3), 617-35.

Giovannini, A., Mayer, C., Micossi, S., Di Noia, C., Onado, M., Pagano, M. \& Polo, A. (2015). 'Restarting european long-term investment finance'. A Green Paper Discussion Document, London.

Hardie, I. \& Howarth, D. (2013). Framing market-based banking and the financial crisis (pp. 1-21). Oxford: Oxford University Press.

Hardie, I., Howarth, D., Maxfield, S. \& Verdun, A. (2013). 'Banks and the false dichotomy in the comparative political economy of finance'. World Politics, 65(4), 691-728.

Hay, C. \& Wincott, D. (1998). 'Structure, Agency and Historical Institutionalism'. Political Studies, 46, 951-957.

Hellwig, M. F. (2010). 'Capital Regulation: Business as Usual?'. Working paper, MPI Collective Goods Preprint, No. 2010/31.

High Level Expert Group (HLEG) (2013). 'Finance for Growth- Report of the High Level Expert Group on SME and Infrastructure Financing'. European Commission: Brussels.

HSBC (2013). 'Money Market Fund ('MMF') reform in Europe'. available online https://www.treasurymanagement.com/docs/HSBC-US-MoneyMarketFund-Reform-Europe-Final.pdf (last accessed 18.03.2018).

Hutter, B. M. (1997). Compliance: Regulation and environment. Oxford University Press.

IMMFA (2013). 'The Institutional Money Market Funds Association's (IMMFA) Views on the European Commission's Proposed Regulation on Money Market Funds (MMFR)'. October 2013, available online http://www.citibank.com/transactionservices/home/oli/files/immfa_summary_reform_1013.pdf (last accessed 19.03.2018).

IMMFA (2014). 'IMMFA Position Papers Regarding the European Commission Proposal for aRegulation on Money Market Funds'. Oktober 2014, available online https://www.immfa.org/assets/files/publications/IMMFA\%20Position\%20Papers\%20October \%202014.pdf (last accessed 19.03.2018).

International Financial Services Center (IFSC) (2013). 'EC proposes Regulation on Money Market Funds'. September 2013, IFSC. 
Kane, E. J. (1988). 'Interaction of Financial and Regulatory Innovation'. The American Economic Review, 78 (2), Papers and Proceedings of the One-Hundredth Annual Meeting of the American Economic Association (May, 1988), pp. 328-334.

Kane, E. J. (2008). 'Regulation and supervision: an ethical perspective'. No. w13895, National Bureau of Economic Research.

Kudrna, Z. (2016). 'Financial market regulation: crisis-induced supranationalization'. Journal of European Integration, 38(3), 251-264.

Langfield, S. \& Pagano, M. (2016). 'Bank bias in Europe: effects on systemic risk and growth'. Economic Policy, 31(85), 51-106.

Lexology (2012). 'European Commission Requests EIOPA to Analyse Solvency II Capital Requirements'. 31 October 2012, online available https://www.lexology.com/library/detail.aspx?g=52c69658-19204121-80e3-0c807dcdb321 (last accessed 2.1.2018).

Lexology (2013). 'ESRB Issues Recommendations on MMFs'. 26 February 2013, online available https://www.lexology.com/library/detail.aspx?g=ef9c8b6e-1699-4a9f-9d02-c93b89cac867 (last accessed 20.03.2018).

Lexology (2016). 'ECON Final Reports on Proposed Securitisation Regulation and Regulation Amending CRR Set out Parliaments Amendments'. 13 September 2016, available online https://www.lexology.com/library/detail.aspx?g=94666b91-9b56-43b1-926f-e89d6326ca80 (last accessed 22.03.2018).

Lysandrou, P. \& Nesvetailova, A. (2014). 'The role of shadow banking entities in the financial crisis: a disaggregated view'. Review of International Political Economy, 22(2), 257-279.

Marin, B., \& Mayntz, R. (1991). Policy networks: Empirical evidence and theoretical considerations. Campus Verlag.

Mayntz, R. (2003). 'Mechanisms in the analysis of macro-social phenomena'. No. 03/3, MPIfG working paper.

Moschella, M. \& Tsingou, E. (2013). Great expectations, slow transformations. Colchester: ECPR Press.

Mudge, S. L. \& Vauchez, A. (2012). 'Building Europe on a weak field: law, economics, and scholarly avatars in transnational politics'. American Journal of Sociology, 118(2), 449-492.

Mügge, D. (2010). Widen the Market, Narrow the competition: banker interests and the making of a European capital market. Colchester: ECPR Press.

Mügge, D. (2013). 'The political economy of Europeanized financial regulation'. Journal of European Public Policy, 20(3), 458-470.

O'Sullivan, M. (2007). 'Acting out institutional change: understanding the recent transformation of the French financial system'. Socio-Economic Review, 5(3), 389-436.

Pagano, M., Langfield, S., Acharya, V., Boot, A., Brunnermeier, M., Buch, C., Hellwig, M., Sapir, A. \& van den Burg, I. (2014). 'Is Europe overbanked?' Report no.4 of the European Systemic Risk Board's Advisory Scientific Committee. 
Pension and Investments (2016). 'European Money Market Reform on Different Path'. 5 September 2016, available online http://www.pionline.com/article/20160905/PRINT/309059989/europeanmoney-market-reform-on-different-path (last accessed 16.10.2017).

Peterson, J. (2003). 'Policy Networks'. In A. Wiener and T. Diez (eds.) European Integration Theory, edn, Oxford: Oxford University press: 105-24.

Plus Company Updates (PCU) (2016). 'Moodys first combined Money Market Funds and ABCP Conference highlights impact of regulatory initiatives for European short term financial markets'. 23 September 2016, PCU: New York.

Pozsar, Z. (2008). 'The Rise and Fall of the Shadow Banking System, Moody's'. Regional Financial Review, 44(7), 1-14.

Pozsar, Z., Adrian, T., Ashcraft, A. \& Boesky, H. (2010). 'Shadow Banking'. Staff Reports 458, Federal Reserve Bank of New York.

Quaglia, L. (2015). 'The European Union and the Post-Crisis Multilevel Reform of Financial Regulation'. In Mayntz, R.: Negotiated Reform: The Multilevel Governance of Financial Regulation, 85- 97.

Rhodes, R. A. (1997). Understanding governance: Policy networks, governance, reflexivity and accountability. Open university press.

Seabrooke, L. \& Tsingou, E. (2009). 'Revolving Doors and Linked Ecologies in the World Economy: Policy Locations and the Practice of International Financial Reform'. CSGR Working Paper.

Streeck, W. (2009). Re-Forming Capitalism: Institutional Change in the German Political Economy, Oxford: Oxford University Press.

Thiemann, M. (2018). Out of the Shadows? A Comparative Institutional Analysis of the Growth of Shadow Banking. Cambridge: Cambridge University Press.

Thiemann, M. \& Lepoutre, J. (2017). 'Stitched on the Edge: Rule Evasion, Embedded Regulators, and the Evolution of Markets'. American Journal of Sociology, 122(6), 1775-1821.

Treasury Today (2017). 'European MMFs: The Way Forward'. July 2017, online available http://treasurytoday.com/2017/07/european-mmfs-the-way-forward-ttia (last accessed 4.12.2017).

True Sale International (TSI) (2015). 'EU-Vorschläge zur Revitalisierung des Verbriefungsmarkts kaum praktikabel, 2. September 2015, online available https://www.tsi-kompakt.de/2015/09/euvorschlaege-zur-revitalisierung-des-verbriefungsmarkts-kaum-praktikabel/ (last accessed 20.03.2018).

True Sale International (TSI) (2017). 'STS - am Ende sehr gemischte Gefühle'. 6 November 2017, online available https://www.tsi-kompakt.de/2017/11/sts-am-ende-sehr-gemischte-gefuehle/ (last accessed 22.03.2018)

Tsingou, E. (2015). 'Club governance and the making of global financial rules. Review of International Political Economy'. 22(2), 225-256.

Whitecase (2016). 'European securitisation: Making a comeback?'. 19 May 2016, online available https://www.whitecase.com/publications/insight/european-securitisation-making-comeback (last accessed 21.03.2018). 
Appendix: List of Interviews

\begin{tabular}{|l|l|l|l|}
\hline 1 & 12.06 .2010 & Head of Securitization, Large French Bank & Paris, France \\
\hline 2 & 15.06 .2011 & Big 4 Auditing Firm, Consultant on Regulation & Frankfurt/Main \\
\hline 3 & 15.03 .2016 & Federal Reserve Regulator, responsible for ABCP & Washington \\
\hline 4 & 22.03 .2016 & Bank manager US, formerly Moodys & Phone Interview, New York \\
\hline 5 & 23.03 .2016 & Wall Street Lawyer; involved with ABCP market & Interview, New York \\
\hline 6 & 20.07 .2016 & ABCP Lobbyist, Conduit Manager & Phone interview, Germany \\
\hline 7 & 19.10 .2017 & Securitisation manager & Phone interview, Germany \\
\hline 8 & 09.11 .2017 & European Commission & Phone Interview, Brussels \\
\hline 9 & 13.11 .2017 & Credit Rating Agency & Phone interview, Germany \\
\hline 10 & 19.01 .2018 & Policy Analyst & Phone interview, Brussels \\
\hline 11 & 26.01 .2018 & ABCP Lobbyist, Conduit Manager & Phone interview, Germany \\
\hline 12 & 13.02 .2018 & MMF Lobbyist & Phone interview, London \\
\hline 13 & 15.02 .2018 & MMF Head of Research & Phone interview, London \\
\hline
\end{tabular}




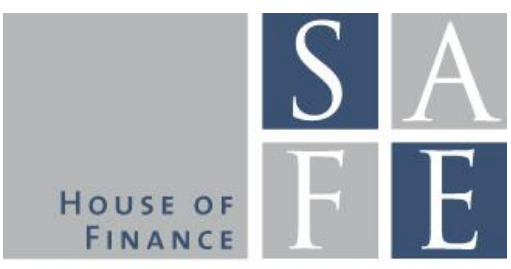

WORKING PAPER SERIES

\section{Recent Issues}

No. 221 Axel H. Börsch-Supan, Klaus Härtl, Duarte N. Leite, Alexander Ludwig

No. 220 Yangming Bao, Martin R. Goetz

No. 219 Andreas Hackethal - Christine Laudenbach - Steffen Meyer Annika Weber

No. 218 Florian Hoffmann, Roman Inderst, Marcus Opp

No. 217 Maddalena Davoli, Jia Hou

No. 216 Stefano Colonnello, Giuliano Curatola, Alessandro Gioffré

No. 215 Zsuzsa R. Huszár, Zorka Simon

No. 214 Edin Ibrocevic, Matthias Thiemann

No. 213 Klaus Gugler, Michael Weichselbaumer, Christine Zulehner

No. 212 Henning Hesse

No. 211 Thomas Mosk

No. 210 Darien Huang, Christian Schlag, Ivan Shaliastovich, Julian Thimme
Endogenous Retirement Behavior of Heterogeneous Households Under Pension Reforms

Local Peer Effects and Corporate Investment

Client Involvement in Expert Advice Antibiotics in Finance?

Only Time will Tell: A Theory of Deferred Compensation

Financial Literacy and Socialist Education: Lessons from the German Reunification

Pricing Sin Stocks: Ethical Preference vs. Risk Aversion

The Pricing Implications of the Oligopolistic Securities Lending Market: A Beneficial Owner Perspective

All Economic Ideas are Equal, but Some are more Equal than Others: A Differentiated Perspective on Macroprudential Ideas and their Implementation

Effects of Government Spending on Employment: Evidence from Winners and Runners-up in Procurement Auctions Incentive Effects from Write-down CoCo Bonds: An Empirical Analysis

Bargaining with a Bank

Volatility-of-Volatility Risk 